\title{
Teachers' Use of Technology and Constructivism
}

\author{
Abbas Pourhosein Gilakjani \\ School of Educational Studies, Universiti Sains Malaysia, Malaysia \\ Email: a_p_g48@yahoo.com \\ Lai-Mei Leong \\ School of Educational Studies, Universiti Sains Malaysia, Malaysia \\ Email:1mleong@usm,my \\ Hairul Nizam Ismail \\ School of Educational Studies, Universiti Sains Malaysia, Malaysia \\ Email: hairul@usm.my
}

\begin{abstract}
Technology has changed the way we teach and the way we learn. Many learning theories can be used to apply and integrate this technology more effectively. There is a close relationship between technology and constructivism, the implementation of each one benefiting the other. Constructivism states that learning takes place in contexts, while technology refers to the designs and environments that engage learners. Recent efforts to integrate technology in the classroom have been within the context of a constructivist framework. The purpose of this paper is to examine the definition of constructivism, incorporating technology into the classroom, successful technology integration into the classroom, factors contributing to teachers' use of technology, role of technology in a constructivist classroom, teacher's use of learning theories to enable more effective use of technology, learning with technology: constructivist perspective, and constructivism as a framework for educational technology. This paper explains whether technology by itself can make the education process more effective or if technology needs an appropriate instructional theory to indicate its positive effect on the learner.
\end{abstract}

Index Terms - Technology, Definition, Role, Constructivism, Benefits, Factors, Learning Theory

\section{INTRODUCTION}

While technology provides many new opportunities for issues like learning styles, student-centered instruction and promotion of higher-level thinking, the teacher's attitudes and beliefs often stop them from fully integrating technology into their course design [1]. This hesitation leads to technology being used as a substitute for other tools in their traditional teaching styles instead of as a new approach to instruction [2]. Many factors appeal to teachers to use computer technology in their classrooms.

These factors include computer self-efficacy, personal technology use, positive teacher attitudes and beliefs towards technology and access to professional development in the computer technology area. All of these are significant in motivating teachers to use technology. However, using technology in the classroom by itself is not effective unless teachers have a theory to model their instruction with.

In order to understand the potential of technology implementation in increasing the teaching-learning process, the effect of constructivism on classroom practices has been studied by many researchers [3], [4]. There is a close relationship between technologies and constructivism, the implementation of each one benefiting the other. According to [5], constructivism is both a philosophical and psychological approach based on social cognitivism that assumes that persons, behaviors and environments interact in reciprocal fashion. Constructivism states that learning happens in contexts and that learners form much of what they learn and understand as a function of their experiences in situation.

Technology is the designs and environments that engage learners. The focus of both constructivism and technology is on the creation of learning environments. These learning environments are as the contexts in which knowledge-building tools and the means to create and manipulate artifacts of understanding are provided through which learners work together and support each other as they use a variety of tools and learning resources in their pursuit of learning goals and problemsolving activities [6]. In this paper, the researchers explain the benefits of the incorporation of technology into the classroom, elaborate successful technology integration into the classroom, discuss factors contributing to teachers' use of technology, state teacher's use of learning theories, examine constructivist perspective, and investigate constructivism as a framework for educational technology.

\section{DEFINITION OF CONSTRUCTIVISM}

Constructivism is defined as the philosophical position which holds that any so-called reality is the mental construction of those who believe they have discovered and investigated it [7]. From this perspective, learning is understood to be a self-regulated process of 
resolving inner conflicts that become apparent through concrete experience, discussion, and reflection [8]. According to [9], constructivism acknowledges that learning is an active and socially dependent construction unrestricted by age or developmental stage, but emphasizes the need to engage students in the design and/or actual construction of personally significant projects.

The basic idea of constructivism is that knowledge must be constructed by the learner. It cannot be supplied by the teacher [10]. He gave the clue of how learning can be nurtured provided by Piaget's definitions of knowledge, which is an interaction between subject and object. It is a perpetual construction made by exchanges between thought and its object. It is not a copy of reality by the concepts of the subject that approaches the object without ever attaining it in itself. Therefore, the construction of knowledge is a dynamic process that requires the active engagement of the learners who will be responsible for ones' learning while the teacher only creates an effective learning environment.

Constructivism is generally considered as a viewpoint in learning theory which holds that a person actively constructs his/her own ways of thinking as a result of innate capacities interacting with his/her experience [11]. From the constructivist's perspective, learning is not a stimulus-response phenomenon. It requires selfregulation and building of conceptual structures through reflection and abstraction [12]. The way in which knowledge is conceived and acquired, the types of knowledge, skills and activities emphasized, the role of the learners and teacher, and how goals are established; all of these factors are articulated differently in the constructivist's perspective [13].

\section{THE TEACHER'S ROLE IN A CONSTRUCTIVIST ENVIRONMENT}

Teacher quality is the single most important determinant of student performance. This is even more significant when applying constructivism [14]. The teacher's knowledge, beliefs, and actions all affect the success of the learner. The most valuable quality of a teacher applying pedagogy based on constructivism is the "instantaneous and intuitive vision of the pupil's mind as it gropes and fumbles to grasp a new idea [8]. Teachers should correct or warrant the knowledge a learner constructs, therefore promoting the development of powerful and effective constructions [15], [16]. They must direct the student to provide experiences that can question or expand upon their previous learning. Teachers must continuously reassure students that they are doing things right, that their thinking has power and their errors are correctable [17]. Teachers should allow students to choose activities, ask students to explain answers, and prompt all students to be involved [18]. A teacher can use invocative acts in which students are encouraged to think at less sophisticated levels of understanding or provocative acts; students are faced with dilemmas or challenges that push them forward in their understanding [19].
The role of the teacher in a class based on constructivism has been summarized by [20]. The teacher should become one of many resources that the student may learn from, engage students in experiences that challenge previous conceptions of their existing knowledge, allow student responses to drive lessons and seek elaboration of students' initial responses, allow students some thinking time after posing questions, encourage the spirit of questioning by asking thoughtful, open-ended questions, encourage thoughtful discussion among students, encourage and accept student autonomy and initiative, be willing to let go of classroom control, promote student leadership, collaboration, location of information, and taking actions as a result of the learning process, encourage students to suggest causes for events and situations and encourage them to predict consequences, extend learning beyond the classroom, not separate knowing from the process of finding out, and insist on clear expression from students because when students can communicate their understanding then they have truly learned.

Many teachers are in favor of adopting constructivist instructional approaches but are unsure of where to begin. The role of the constructivist teacher is to create a learning environment that is invigorating, interactive, immersive, and informative [21]. The roles of teachers are didactic and well-established. The largest amount of teaching activity in educational settings involves telling things to students. More recent analyses of teaching indicate that little has changed since then. The role of the teacher in a constructivist environment is not just viewed with a different focus, but through a distinctively different lens [22]. The learning that is captured within a constructivist environment is pictured as student centered, collaborative, mindson, authentic and action packed [23]. For some teachers, this rings with the magic of beanstalk growth, while others will be disenchanted with a perceived lesser role of coach, facilitator or guide. The importance of changing the role of the teacher in the learning process has been emphasized by [24]. The teacher becomes the facilitator or coach. He/she does not possess all the knowledge, graciously allowing it to trickle down, to the great fortune of the learner. This may be cause for anxiety for teachers as uncertainty develops and envelops their new role [24].

It is important for the teacher to utilize errors as a way of providing feedback for the learners' understanding [13]. In a constructivist environment the best hope for the educator is in the possibility of intervening in the learning that is occurring, rather than being in charge of the act of learning. If teachers desire to intervene in the learning game, they must be aware that they are not the one in possession of the puck [25]. Teachers who are interested in assessing the degree of constructivism used within their classroom would benefit from reading [20], who refers to [26] checklist. Brooks and Brooks suggest 12 strategies for teachers to exercise in order to move towards a more constructivist approach: 
- encourage and accept student autonomy and initiative;

- use raw data and primary sources, along with manipulative, interactive, and physical materials;

- use cognitive terminology such as "classify," "analyze," "predict," and "create";

- allow student responses to drive lessons, shift instructional strategies, and alter content;

- inquire about students' understanding of concepts before sharing their own understandings of those concepts;

- encourage students to engage in dialogue, both with the teacher and with one another;

- encourage student inquiry by asking thoughtful, open-ended questions and encouraging students to ask questions of each other;

- seek elaboration of students' initial responses;

- engage students in experiences that might engender contradictions to their initial hypotheses and then encourage discussion;

- allow wait time after posing questions;

- provide time for students to construct relationships and create metaphor;

- nurture students' natural curiosity through frequent use of the learning cycle model (The learning cycle model consists of discovery, concept introduction, and concept application).

Constructivist teachers are viewed as the "anything goes" type. Constructivism is equated with low structure and permissiveness imposing predefined learning goals or a learning method is somehow interfering with students' construction of meaning. In extreme cases, that may be true. Yet to help students become creative, some kind of discipline and structure must be provided [27]. As the teacher relinquishes control over content, pacing, and specific activities, students need corresponding increases in decision and performance support. Poorly planned learning environments are vulnerable to failure due to lack of support, leaving students feeling stranded and faced with unreasonable performance expectations. This problem is complicated by the fact that learners differ dramatically in their need for support [23]. Constructivism is teaching with an approach that seeks opportunities for students to analyse, investigate, collaborate, share, build and generate based on what they already know, rather than store away facts, skills, and processes they can later parrot. The use of metaphors during instruction is encouraged [28], [29]. To do this effectively, [28] and [24] believe that a teacher needs to be a learner and a researcher. Giving teachers the opportunity to work as a learner, helps them overcome anxieties about novel situations.

\section{BENEFITS OF THE INCORPORATION OF TECHNOLOGY INTO THE CLASSROOM}

Several researchers have performed studies in an attempt to find out if the incorporation of technology into the classroom helps students, and if so, what factors contribute to a positive outcome [30]. These researchers have looked at individual pieces such as the effects of specific software use with reading and mathematics curriculum, while other research focuses on the overall impact of installing and using computer-based technology in the classrooms. The important thought to keep in mind is that the interest of researchers on the effects of technology on education has been flourishing in the past years giving teachers the ability to explore these new waters and adapt their teaching accordingly. There is enough variety among recent authors to warrant the making of generalizations that can be applied to any current classroom situation. One of these generalizations states that the introduction of technology into the classroom environment exerts a change in the way students learn.

For the most part, changes take on a positive direction by creating a learning atmosphere centred around the student rather than the teacher. This is due in part to the replacement of the traditional seat-work with the use of computers as learning tools. Instead of the static teachercentred environment where the students act as receivers of information from a single source, the classroom becomes an active setting full of meaningful activity where the student is made responsible for his or her learning. The students are engaged in meaningful activities such as problem-based learning projects, browsing the Internet in search of information for a report, or the preparation of presentation assignments. Software and hardware become tools used by the student to create a product to be presented to teachers and fellow students so that they may review, learn, or critique in a collaborative manner [30].

All of these factors create an increase in student interest and engagement with the subject being studied, and high student attention to independent research. The teacher takes the role of a facilitator who directs students to an achievable goal. Teachers work with students in such a way that there is an increase in critical thinking skills and the use of the computer as a learning tool. They make practical choices of tools and media that will shape the way students learn, express themselves and perform [31].

Another positive and desirable effect of bringing technology into the classroom is the increase in collaboration among teachers and students. This expanded interaction is manifested through the frequent trading of computer skills, shared tips about technology, and the role of the student as a tutor. By allowing students to become assistants in the instruction process their self-worth and confidence increase. They are granted the opportunity to reinforce ideas and skills already learned. These are competencies that are not necessarily shared only with other students. In fact, often the student is able to help the teacher on technology tips that the student has had the time to master while the teacher works on directing the instruction as a whole [32]. This adds to the learner's increase in meaningful use of technology and collaborative participation.

The forgoing description of the computer-based classroom represents an authentic learning experience 
that fosters student responsibility. Teachers report that the introduction of systems such as the Internet and email encourages student-directed learning and the acquisition of responsible behaviours [31]. This is due in part to the fact that students do not need to rely on the teacher to locate new sources of information and they can use email to place their homework and projects on a location that is available at all times. In addition, the independent use of the Internet gives the student a certain amount of self-direction.

Once they have received general parameters for working on a specific project, the students can determine the route for achieving the goal presented by the teacher. Another benefit of the computer-based classroom is the increase in student motivation. Research data demonstrates that students in a classroom with laptops are enthusiastic about having the technology and find learning environment more enjoyable than students who do not work with laptops. These students often go beyond the requirements set forth for any given assignment and show increased academic engagement. Increase in motivation leads to the creation of sophisticated activities such as different types of written expressions, multimedia products, and the analysis of data. A sense of pride and empowerment becomes characteristic of the participants [32].

All the benefits of technology presented so far converge on student achievement on subject areas and evaluations. How do students in computer-based classrooms perform and score on tests? Research has concluded that when students are engaged in technology-immersed classrooms, there is a gain in achievement in all subject areas [33], [34], [35], [36].

The use of computers in mathematics by eighth grade students was significantly related to academic achievement and the social environment of the school. However, he stipulated that greater student scores might be achieved when students use computers to apply higher-order skills such as solving simulations rather than drill and practice exercises [33]. Students who edited their papers at school through the frequent use technology were likely to obtain higher total English and language arts test scores and achieved higher writing scores [34].

An extensive study was performed on 21 treatment schools by [36]. The purpose of the research was to evaluate technology immersion in these middle schools and the corresponding effects on test scores and data was collected for four years. The use of technology in the classroom correlated with test scores but the result was positive only in schools where the immersion program was implemented with higher level of fidelity. Thus, the actual implementation of the program was a predictor in the test. Schools that implemented the program first enabled their students to reach higher test scores. The authors acknowledge that positive attitude towards the use of technology in the classroom will draw the greatest advantage.

Computer use in the classroom correlates to improved achievement on the part of the student but [35] cautions that technology alone is not a cure for poor scores. She reports on a research project that sought to find out what elements of technology use in the classroom truly affect student scores. The process included 13 schools that had adopted reading and mathematics software to complement their core curriculum. Seven schools had achieved high scores in both reading and mathematics, while the other six had scored poorly.

The data collected during this study concluded that the software itself was not responsible for higher or lower achievement. Instead, elements such as a consistent instructional vision, principal support, teacher collaboration, and satisfactory on-site technical support were essential for achieving an acceptable learning experience and competent test scores. In addition, Means suggests that the data confirms that classroom management and weekly review of software reports for all students are major assets of a successful program using reading and mathematics software [35].

\section{SUCCESSFUL TECHNOLOGY INTEGRATION INTO THE CLASSROOM}

Successful technology integration is what makes a difference in reforming a classroom. Integrating technology is not easy, it is a three-step process that involves the teacher learning the technology and using the technology in teaching and learning so that student learning is enhanced [37].

Effective technology integration can be affected by certain factors. Six factors that affect successful technology integration were identified by [38]. They are lack of resources, lack of specific knowledge and skills, institutional structures, teacher attitudes and beliefs toward technology, and types of assessment and subject culture. The changes in computer-based technologies over the last ten years have been incredible and it is difficult for schools and universities to stay in step with the current industry norms. Computers that were top of the line five years ago are horribly outdated today. Updating computer resources is extremely expensive and combined with the budget constraints that schools and universities are now facing with and it is no wonder that many institutions lack current technological resources.

Time is another resource that is severely lacking. Unfortunately, teachers are finding a decreasing amount of time allowed for preparation while responsibilities increase. This occurs in spite of the fact that technology integration is demanding more time, including searches for appropriate websites, preparing PowerPoint presentations, downloading videos, and more. Therefore, teachers need more time to prepare and they are required to be on-site to provide technical support in order to offer a quick and adequate response when computers fail [38].

According to [38] teachers need specific technological knowledge and skills in order to use computer-based technologies for instruction. It is not enough for professional development to focus on how to operate a specific program but additionally there needs to be 
guidance in how to use the program to increase student learning. Emphasis also needs to be placed on classroom management as it relates to computer-based technologies. Additional rules and procedures need to be incorporated once computers, printers, and other electronics are added to the classroom mix.

Institutional factors such as lack of planning on the part of the administrators further hinder technology integration according to [38]. For instance, there was a certain administrator who proudly announced at a staff meeting that the school had recently acquired two computers that could be checked out for classroom use. There was no mention of who could instruct the teachers on how to use them or even what were the computer capabilities. A better mode of introduction could have been for the administrator to plan ahead and serve as a role model by demonstrating the use of a computer at the staff meeting. Teacher attitudes and beliefs are another factor on the road to successful technology integration. Teachers should be exposed to research that focuses on technology integration benefits. If a teacher views computer-based technology as another form of babysitting, he or she will use it that way. Conversely if teachers believe that integrating technology enhances student learning they will find ways to use this technology in their classrooms.

The pressure of high stakes testing is also a factor to the successful integration of technology [38]. With all the assessments and data collecting that fall on the shoulders of teachers, there is little time to explore and integrate new technologies. Additionally high stakes testing has shifted the focus from using computer-based technologies in teaching to using computer-based assessments for the collection of student data. The last factor that [38] identified is subject culture. Subject culture is the rules and practices that have developed around a specific institution subject. Teachers are more reluctant to integrate technology if the subject they teach seems incompatible with computer-based technologies. They need to be shown real examples of how technologies can work within the framework of their job.

What can schools and universities do in order to integrate technology successfully? Some suggestions were mentioned by [38]. Institutions' administrators and teachers need to join together to implement a technology plan that considers integration strategies along with purchasing decisions. Professional development needs to be at the forefront in order to assure student learning and to change the attitudes and beliefs of teachers unfamiliar with the benefits that technology has to offer. And finally, the technology plan must be closely aligned with the curriculum standards. Teachers need to know what instructional approach is the most effective when integrating computer-based technologies in the classroom. Four instructional approaches were compared for effectiveness and efficiency by [39]. The instructional approaches are referred to as hypermedia learning (Tell Me), observational learning (Show Me), self-explanation-based learning (Let Me Explain), and inquiry learning (Let Me Investigate).
Hypermedia learning (Tell Me) is computer-based learning that can be used interactively. Learners can pick and choose what they would like to explore. One characteristic of this type of learning is that it has a high level of interactivity. The drawback is that often the student has trouble deciding upon which content to concentrate, and in what order she should work. The researchers found that this type of learning is very efficient (takes less time) but is not as effective as the other instructional approaches [39].

Observational learning (Show Me) is a computerbased learning environment where an expert presents and explains the task or procedure while the learner observes and performs the task being shown. This is thought to be effective because the expert explains the rationale behind the procedure. In the computer-based environment, the expert can be a person in the room or a person/character on the computer screen. The problem with this integration strategy is that the learner is a passive participant in the process, which may be appropriate when considering the grade level. This type of instruction was shown to be efficient but not as effective [39].

In self-explanation-based learning, a number of worked out examples are presented step-by-step and learners are then given problems to solve using the previous examples. This type of computer-based instruction was shown to be the most effective because learners focus on understanding the process and selfexplain it to themselves. This type of integration environment was also found to be the least efficient since it is very time-consuming. This type of integration seems suited to specific subject matters like math, science, art, and any others that involve step-by-step processes [39].

Inquiry learning requires the learner to develop a hypothesis, conduct experiments and draw conclusions in order to confirm or disprove the original hypotheses. This type of learning leads to a deep understanding of the subject matter. The difficulties for learners are in developing a hypothesis and drawing conclusions that are supported by the evidence. This type of integration is obviously suited to scientific study and researchers found it to be effective but not as effective as selfexplanation-based learning. It is also time consuming [39].

What do we learn by analyzing the results? The approaches that are the most effective are the ones where the learners had to generate parts of the subject matter and the ones that were the least effective are the ones where the subject matter is basically presented to the learner. Obviously one could argue a case for the use of any of the four instructional strategies. The key is to use the integration strategy that is best suited for the age group, the concept(s) being presented, and the learning goal(s). Additionally time constraints need to be considered and planned for. But most of all, teachers need to be instructed in how to incorporate all four instructional approaches so that computer-based 
technology will be integrated successfully and effectively [39].

\section{FACTORS CONTRIBUTING TO TEACHERS' USE OF TECHNOLOGY}

There are many factors that encourage a teacher to use technology in his/her classroom. These factors include computer self-efficacy, personal technology use, positive teacher beliefs and attitudes towards technology and access to professional development in the technology realm. All of these are important in motivating a teacher to use technology. However, using technology in the classroom by itself is not effective unless the teacher has a theory to model the instruction with [40]. In this section, the researcher reviews the factors that influence teachers to use technology in their classroom and attempt to find a correlation between technology use and teaching practices. In the more than two decades since technology applications such as overhead projectors, VCRs, slides, smart boards, computers, software, internet, etc. have been introduced to the education system, the resources for teaching have significantly changed. There are many advantages in using technology in educational settings. For example, they make the learner more interested about the subject, they decrease learning time, and they provide opportunities to learn in non-traditional ways. Technology is transforming the way we learn. By transforming the process, it is also transforming the outcome [40].

The introduction of technology in the teaching methods class is noteworthy especially if we consider the impact that computers and the Internet have on the new generations of students entering the education system. According to [41], the millennial generation, generally defined as students born after 1982, differs from previous generations in specific characteristics. These new students gravitate toward group activity and are fascinated by new technologies. They are actively engaged on the Internet playing videogames and chatting, actions which do not coincide with the traditional lecture style practiced by older generations of teachers in most classrooms. The learning styles of new generation lean toward teamwork, experiential activities, multitasking, and the use of technology. For these young learners, technology is a natural part of their everyday environment. The younger the students, the more likely they are to have the higher exposure to technology and use of the Internet, which creates greater disparity between the students' learning styles and the teachers' knowledge of and ability to use technology [41].

Students in a teacher training program were not sufficiently exposed to technology integration as part of their teacher preparation program but that they demonstrated a positive attitude toward using technology while teaching [42]. University instructors should "upgrade" their technology skills to a level that would allow incorporation of the new technologies in their teaching in order to develop higher order thinking skills in their students. The use of technology to promote higher-order learning can only occur when classroom teachers are trained to include new technologies and blend them intelligently into their curricula [42]. Incorporating learning about technology integration in the teaching methods courses and the placement of teacher candidates with technologically proficient mentors develop this skill during their teaching practicum [42].

A variety of factors affect teachers who use technology in their classrooms either in their pre-service training, their personal lives, or during their teaching career that have influenced them to do so. One of the major factors that influences teacher technology use in the classroom is whether a teacher received technology training in their undergraduate coursework. If teachers are appropriately taught how to use technology before they enter a real classroom, their computer self-efficacy will increase, and their likeliness to use technology in the classroom will improve. Studies have shown that when pre-service teachers attend educational technology courses that emphasize technology use skills as part of the curriculum, the pre-service teachers' computer selfefficacy improves [43].

There is a positive relationship between a teacher's computer self-efficacy and technology integration in the classroom [43]. In a study conducted by [44] he noted that since technology is frequently used by youth these days, sometimes student knowledge of technology can trump teacher knowledge. In these situations the roles of teacher (expert) and student (novice) can sometimes become interchanged and some teachers may feel embarrassed by this situation. For the most part, teachers want to feel in control in regards to technology in the classroom. Fifty-five percent of teachers surveyed strongly agreed with the statement "A teacher's proficiency with computers will affect his or her willingness to integrate technology into the curriculum" [44].

A teacher's personal computer use outside the institution is the most important indicator of a teacher's technology use in the classroom [45]. In the [44] teachers were asked how long they had owned a personal computer. The teachers were shown a mixture of 11 types of software applications and asked to rate their knowledge of each one. It was found that teachers who possessed high amounts of knowledge in regards to the 11 software applications let their students use computers one more day per week on average than teachers who were less proficient. Findings from this study [44] revealed that if teachers were regularly using technology at home they would feel comfortable using it in the classroom. When teachers have positive beliefs and attitudes toward computers, technology will be effectively implemented into the classroom. Some of these positive beliefs and attitudes include the expectation that they will be able to implement the technology successfully and that implementing technology into the classroom is valuable to student's learning [45].

The other important factors that contribute to 
teachers' use of technology in teaching include modelling by colleagues, expectations by the administration of academic institutions, positive experiences with computers in teaching, and teacher beliefs and attitudes about technology in teaching. Researchers have shown that a key factor in encouraging teachers to introduce and sustain the use of multimedia in classroom instruction is modelling [46], [47], [48], [49], and [50]. In research with high school teachers engaged in professional development for technology integration in the United States, [49] found that lack of modelling by the mentor teacher was a disabler while modelling concrete uses of technology in specific subject areas and grade levels was found to be an enabler. In addition to effective mentoring, encouragement, and modelling, Bullock found that clear expectations, easy access to technology and technical support, and positive experiences with computers in classroom settings facilitated the necessary skill development for teachers to use technology on a regular basis.

Three important factors were found by [51] that need to be operational: (a) access to hardware, software, and technical support; (b) teacher educators' relationships with key technical players; and (c) positive organizational attitudes toward technology use emphasizing the organizational context in which technology innovation takes place. Technology integration is a social process that must have administrative institutional support to succeed. Another factor contributing to teachers' use of multimedia is attitude toward educational technology [51]. Pre-service secondary level teachers learning to use technology in their classrooms were surveyed by [52]. Instead of viewing technology as a collection of skills to be acquired, the ideology of life-long learning emerged with pre-service teachers developing self-concepts of themselves as technology users. Most teachers who use multimedia understand that technology does not replace good teaching; instead it opens new horizons for discovery and exploration. Furthermore, teachers should not attempt to use technology for technology's sake; for example, implementing computers in classroom settings for repetitive drills which are devoid of contextual grounding [48].

Universities need to move away from a technology assessment of Information Technology (IT) to one which focuses on how IT contributes to realizing lifelong pedagogical goals and objectives [53], [52]. In a study examining the conditions of an educational institution associated with the effective use of computers, [47] measured a socio-demographically heterogeneous group of American educational institutions. While some were not technologically advanced, some were on the leading edge of Internet use, being among the first to have high-speed Internet connections linked to supportive intermediating organizations such as science museums, university research and development programs with strong technology investment ambitions. According to [47], the percentage of teachers requiring their students to use computers during class time doubled, from roughly $25 \%$ of all teachers to $50 \%$ of all teachers. Further, Becker measured variables pertaining to teacher use of computers by correlating the complex relationships among pedagogical beliefs, instructional practices, and teachers' use of technology. Becker observed that exemplary teachers were better-educated, taught classes with fewer students, and were more likely to report constructivist teaching practice than were teachers who had not used computers with their students. As well, those teachers experienced more problems with their institution's computer infrastructure than other teachers suggesting they made greater demands on the support and maintenance team than other teachers did. Becker outlined the following recommendations for educational institutions wishing to support teachers in the successful use of technology: (a) a full-time computer coordinator, (b) teachers given time and resources, and (c) establishing a pattern towards using computers for important activities (for real world purposes in contrast to classroom drills).

Another contributing factor for teachers' use of multimedia is promoted by [46] who emphasized the view that technology should be a tool for learning content, instead of making technology the content. [46] endorsed the need for teachers to rethink the uses of technology. Further, [46] suggested that we can model an orientation toward embracing the new and being careful in our critical review of its impact on the teaching and learning. Most teachers would agree, as [46] suggested, that the classroom needs to be a human community that prepares students to live in the real world which is becoming increasingly technology-based. It is necessary to rethink the length of time it takes for teachers to become accomplished in using computers in classroom instruction [54]. It takes five to six years of collaboration with colleagues in a functional technological environment to achieve the integrated use of multimedia curriculum [54].

Teachers who are using instructional technology in classroom settings need high-level support from experts to keep hardware running and to learn various software programs [55]. Peer mentoring, peer workshops, electronic message boards can inspire and support teachers involved in multimedia curriculum development. Teaching styles, like learning styles, are highly personal and influenced by intrinsic and extrinsic factors [56], [53]. A re-visioning of educational goals is one of the needed organizational and/or systemic changes required [57]. The culture of autonomy has come under pressure in the past decade giving way to a culture of collaboration. The research by Carroll et al., identified three levels of knowledge sharing which involved: (a) tangible resources (websites, lab equipment); (b) plans and objectives (lesson plans, worksheet templates); and (c) prototypes (online reports, project summaries, and photos). This collaborative model, facilitating the functional use of technology in education, is in direct contrast to the isolation typical of 
traditional teachers who manage their own resources and rarely share their pedagogical practices [58].

With regard to teacher personal factors, it is found that teachers' attitudes to and understanding of technology use affect their technology use in instruction [59], [60], [61], [62], [2], [45], [63], [64], and [65]. For example, if teachers perceive technology as a threat to their traditional teacher-centered methodology in which they have received years of training, they may resist the use of technology [64]. Similarly if teachers adopt a slow revolution or an instrumentalist view of change, they will not resist the use of technology, but will use technology mostly for instructional preparation and communication [59]. In a study on the discrepancy between teacher beliefs and practices in technology integration in Taiwan, [62] found that reasons for the inconsistency include teachers' limited or improper theoretical understanding on student-centered instruction and technology integration or know how to transfer theoretical concepts on technology integration into practice, e.g., how to design technology-based learning activities that would facilitate students' active knowledge construction; and teachers' other conflicting beliefs such as the conflict between the pressure to cover content due to the test-driven culture and the need to allow students to explore content through technology.

Teachers' technology use is also found to be related to their expectancy of success and perceived value of technology. Teachers who believed that they had the skills to implement computers successfully and who valued the outcomes associated with integration were more likely to be at the high end of the technology user spectrum [45]. In a similar study of English as a Foreign Language (EFL) teachers' technology use in classrooms in Korea, [65] revealed that internal factors such as teachers' limited computer skills, knowledge about computers and beliefs and attitudes of computer assisted language learning significantly affected teachers' decisions on the use of technology in teaching. In addition to teacher beliefs and attitudes, [45] also found that teachers' personal use of computers outside of teaching activities was the most significant predictor of teacher use of technology in the classroom. That is, teachers' access to computers outside of teaching has a positive influence on their computer use in the classroom. Therefore, to understand teachers' practices in technology use in instruction, it is important to examine teachers' perceived value of technology and their self-efficacy in technology as wells as their use of technology outside of classroom.

Another personal factor is related to the relationship between teachers' pedagogical practices (such as teaching approaches) and technology use. In their study of 2,213 teachers' perceptions of technology implementation in the province of Quebec, Canada, [45] found that teachers who preferred more student-centered approaches are more likely to integrate computer technologies more frequently and report themselves as being at a more sophisticated stage of integrating computers in classrooms. In contrast to these findings, several studies [62], [2] have found disconnection between teachers' reported teaching styles and their technology use in classroom. In his study of 47 teachers in the US, [66] found that teachers who adopted more student-centered, progressive teaching practices did not regard technology as catalyst for change in their teaching practices. Similarly, [62] found high levels of agreement on student-centered concepts among the Taiwanese teachers studied, but the participants' instruction remained teacher-centered and lecture-based, and their technology use was to support such instruction. These contradictory findings from different countries and contexts suggest further research is needed to examine the relationship between teachers' pedagogical beliefs, attitudes, and technology use.

Contextual factors such as teacher professional development in technology integration are also found to affect teachers' technology use. Inadequate teacher training is often cited as the most serious obstacles in helping teachers learn how to use technology in their instruction [67], [68], [69]. For example, [69] found that due to the lack of information technology experts or teachers, $46.3 \%$ of the 378 teachers in his study reported that no professional development on technology integration was offered in their educational institutions in China. In addition to inadequate training, the kind of training teachers receive also matters. There is an agreement that the traditional workshops or summer "institutes" well removed from classroom practices are often not effective in helping teachers learn to integrate technology into the instruction.

Effective professional development must be sustained, content-focused, and collaborative to effect change in teacher practices in ways that ultimately improve student learning [70], [71], [72]. A focus on a specific content area or a particular pedagogical strategy will enable teachers to take this new knowledge from the professional development and integrate it with their classroom practices. Therefore, teacher professional development in technology cannot just focus on technology applications; it must connect with a specific curriculum and subject area and with specific attention to the pedagogical practices associated with the subject area. Since the effectiveness of technology integration is more rooted in pedagogical and design principles, rather than technology itself [61], [62], and [63], teacher professional development must focus on not only how to use a particular hardware or software, but also on how it is used in alignment with more effective pedagogy, content, and context.

Inadequate technology support in hardware/software stability can be considered as other contextual reasons. Several factors were summarized by [70] that inhibited the teachers' technology integration in the high access, technology-rich environment among their 2004 participants. These factors include the importance of hardware/software stability and technical support, the lack of effective training, lack of involvement in planning for technology integration, and lack of material support (e.g., teachers reported having to periodically 
spend their own money for unimportant devices and supplies such as computer cables, which discouraged them from using computers). These findings suggest that in order to understand how technology is used by teachers, it is necessary to examine teacher beliefs and attitudes and the varied external factors that may influence their technology uses and classroom practices.

\section{THE ROLE OF TECHNOLOGY IN A CONSTRUCTIVIST CLASSROOM}

Technology is no longer a luxury. People are used to fast paced, multi-sensory, highly interactive comfort and convenience all around them. They are now used to processing and evaluating data in 30 second Mc segments rather than one hour lectures. In order to capitalize upon "life in the real world", we must concede that technology in classrooms is no longer a luxury. If education is to be pertinent, productive, progressive and proficient then the fever of technology can no longer be starved, but must be fed, embraced and embodied within our institutions; making every attempt to fuel it rather than cool it [29]. Computers in the home are ironically the biggest source of change in education. He argues that for this reason students will be less and less willing to be educated in ways that are inferior to what they can achieve at home with their computer [73].

Constructivists do believe there is a place for practice and drill. They recognize the fact that learners require opportunities to assimilate new information in repetitive and multiple ways. Computers can serve as coaches by locating the problem and allowing for as much rehearsal, practice and help as necessary to accomplish the task [25]. The use of computers can enhance cognitive powers of students during thinking, problem solving and learning. We are inundated with technology pervading every aspect of our lives. Yet within educational institutions, the amount, quality and expertise in technology is grossly insufficient [74]. The power of the computer would one day match the power of the human mind [75]. Learners would be able to act and learn in an environment that would provide them with the choices, tools, and constructs to help them learn, and not merely instruct them [75].

Technology is increasingly being touted as an optimal medium for the application of constructivist principles to learning. Numerous online environments and technology-based projects are showing that theory can effectively guide educational practice. Software can be used in constructivist ways whereby students can design and create artwork, explore simulations, problem-solve in multimedia presentations, experiment in virtual worlds, participate in musical creations, investigate web sites, or robotic constructions. These complex, collaborative and authentic projects will challenge the ways in which students learn and understand. These types of activities will maximize their learning opportunities rather than minimize the mind by copying information onto word processors [13].

Technology can serve a variety of purposes. It can make use of anchored instruction [77]. Narrative anchors assist the learner in attempting to solve complex problems with realistic videodiscs. The videodiscs contain necessary information for solving the problem. Learners must determine the relevant information and develop strategies for understanding and then solving the problem. Constructivist research findings in terms of context, relatedness and active, minds-on engagement in the learning process have yet to be fully interpreted and translated into software design [78]. The use of computers as workbooks is not compatible with constructivist thinking because children are not allowed to manipulate and change the information, but simply have to choose the right answer [79].

Three types of learning environments were defined by [23] that involve technology in varying degrees. Computer microworlds are closed, self-contained systems that may or may not exist within a larger classroom environment. Learners interact mainly with the computer system, this may be effective for homeschoolers, and multi-grade classrooms. Classroom-based learning environments are where various technologies function as tools to support the learning environment. Wilson sites Vanderbilt's anchored instruction as an example of this. Virtual environments are mainly open systems that allow for interaction among other participants, resources and representations available virtually.

Some important guidelines for the placement and use of computers were established by [80].

1. Seek out open-ended projects that foster students' involvement with a variety of materials, treating computers as just one more material, alongside rulers, wire, paper, sand, and so forth.

2. Encourage activities in which students use computers to solve real problems.

3. Recognize the unique qualities of computers, taking advantage of their precision, adaptability, extensibility, and ability to mirror individual students' ideas and constructions of reality.

4. Take advantage of such new, low-cost technological advances as temperature and light sensors, which promote integration of the computer with aspects of the students' physical environment.

Better learning will not come from finding better ways for the teacher to instruct, but from giving the learner better opportunities to construct [80]. It may hinder the very process of constructivism if technology is used in precisely the same format as the existing tools we now have [81].

\section{TEACHERS' USE OF LEARNING THEORY MAKES TECHNOLOGY MORE EFFECTIVE}

Neither using technology nor a learning theory independently makes a productive class. Technology use should be embedded within a learning theory to support the methodology [82]. In the majority of today's classes the instruction is based on traditional learning theories where technology is being used only as a tool in replacement of traditional tools. For instance, teachers 
use Power Point slides instead of textual handouts or writing on the blackboard. The question is: Does technology by itself make the classroom effective, or do you have to have a model or instructional theory to integrate technology in an effective way? Do we need to have an appropriate learning theory as a framework in which our educational outcome (learner) can be more creative and productive? [83]. These research findings suggest that teachers cannot rely on technology tools or learning theory independently. These two variables must come together to make a productive classroom environment. Which learning theory works best with technology tools to accomplish this goal?

\section{LEARNING WITH TECHNOLOGY: CONSTRUCTIVE PERSPECTIVE}

A distinction was made between learning from computers and learning with computers. Much of the early research and development with technologies considered the enhanced learning that could be achieved when computers played an important and key role in delivering content and creating learning opportunities to help students make meaning and develop an understanding. In such settings, there was a distinctly diminished role for the teacher [74]. The more opportunistic and effective uses of technologies in classrooms are those where learning is achieved with the aid of technology, and the resulting environment is one where the technology supports and scaffolds the learning rather than being the object or derivative of the learning [84]. In a constructivist-learning environment, technology plays a purposeful role in the day-to-day activities but does not become the object of instruction [85]. When used in a constructivist manner, students use technologies to a) manipulate data, b) explore relationships, c) intentionally and actively process information, d) construct personal and socially shared meaning, and e) reflect on the learning process [86].

According to [87], the technological applications which support learning in such ways are often described as cognitive tools and more research is now showing the benefits to be derived from such applications. Cognitive tools describe such applications as (a) calculators, (b) databases, (c) spreadsheets, (d) communications software, (e) semantic network tools, and (f) knowledge construction tools. The critical attribute of cognitive tools is not in the information and knowledge that they carry, but the forms of learner activity and engagement that they support and encourage. Cognitive tools still need the informed teachers to design and supervise the learning activity, but they act to amplify and distribute the cognitive tasks through their design and application. The idea of mind-tools was developed by [88]. Computer based tools and learning environments have been "adapted or developed to function as intellectual partners with the learner in order to engage and facilitate critical thinking and higher-order learning" (p. 11). According to him, the role of a mind-tool is to extend the learner's cognitive functioning during the learning process and to engage the learner in operations while constructing knowledge that they would not have been able to accomplish otherwise. Mind-tools enable learners to become critical thinkers. When using cognitive tools, learners engage in knowledge construction rather than knowledge reproduction. By using available software, learners use technology to both construct and represent knowledge.

Computers can successfully increase the problem solving abilities of the students by using project-based learning (PBL) activities; because they are used in an environment where people are drawn to collaborate naturally as a result of their cultural expectations. An assessment of PBL was performed in four elementary schools by administering teacher questionnaires and interviews, and a survey of parents. The informants reported that PBL had a variety of positive benefits for students such as attitudes towards learning, work habits, problem-solving capabilities and self-esteem [89]. Teachers' beliefs about themselves and their roles in the classroom, as well as their philosophy of education had a central place in shaping the nature of their computer use. Those teachers who saw learner-centered classrooms and authentic learning tasks as central to the success of their students were more likely to use the technology on a continuing basis [90]. Technology increased the complexity with which students could deal successfully and created a multiplicity of roles, leading to student specialization. It allowed in-depth exploration of a smaller number of ideas and related facts around authentic, challenging tasks. They state when students are using technology as a tool or a support for communicating with others, they are in an active role rather than the passive role of recipient of information transmitted by a teacher, textbook, or broadcast. The student is actively making choices about how to generate, obtain manipulate, or show information [91].

Hypermedia allows users to enter virtual environments that include text, sound, visual images, animation, and video. Students who used hypermedia demonstrated increased ability to convey insight and individuality, greater descriptive detail, and unique perspectives [92]. In the USA, The Challenge 2000 Multimedia Project supported by multimedia gives students opportunities to use technology effectively in the planning, development, and presentation of their projects. Students who took part in this project had better results than comparison students on content mastery, audience sensitivity and coherent design [93].

\section{CONSTRUCTIVISM AS A FRAMEWORK FOR EDUCATIONAL TECHNOLOGY}

According to [2] article, there is a connection between teachers with constructivist instruction styles and their technology use in the classrooms. Evidence suggests that constructivist teachers are more likely to use technology in their classrooms and integrate technology into their lessons more than teachers who follow other philosophies of learning. There is a positive correlation between teachers who have student-centered beliefs about instruction and how often they use technology as a 
way to increase student learning. This relationship between technology use and constructivist teaching practices indicates that constructivist-minded teachers advocate technology as a worthwhile learning tool in their student-centered classrooms. The combination of constructivist learning theory and the use of technology seem to produce the best applications of technology tools to facilitate course design. Instead of being limited as a part of the existing traditional approach, when used with constructivist theory technology seems to change every aspect of instruction, from course design to delivery methods and even evaluation [83]. This willingness to not only use technology in learning environments, but to allow the technology to change the instructional approach is not common among teachers today. Having a preference for constructivist teaching methods increases the likelihood that a teacher will use and integrate technology in their instruction [83].

The [44] study conducted a research project that targeted teachers in the Silicon Valley in California to find out what factors mainly influenced their technology use in the classroom. Findings revealed that three major factors influenced teachers' technology integration practices: 1) If teachers had been exposed to technology in their teacher training programs, technology was used more frequently by the teacher and students than in other classrooms, 2) Technology was used more frequently by the teacher and students in classrooms where teachers possessed an understanding of software applications, 3) If teachers held constructivist beliefs, technology was used more frequently by the teacher and students than in other classrooms. Constructivist teachers pattern their instruction after the old Chinese saying: "Tell me and I will forget; show me, and I may remember; involve me and I will understand" (p.47) which focuses on student engagement in the learning process. Constructivist teachers advocate for student use of technology to build their own understanding of information by incorporating authentic experiences into project-based learning situations In a literature review produced by [94] they explain that when teachers blend technology into constructivist learning situations, student achievement is positively impacted [44]. For his research design, [44] had a constructivist beliefs scale created. This scale was used to compare groups of teachers who answered "yes" to the question "Have you ever created technology-based projects for students?" with those who answered "no". Teachers who indicated that they "Integrate technology into their lessons whenever possible" (p. 48) scored significantly higher on the constructivist belief scale than their colleagues who did not. Results indicated a positive relationship between teachers who used technology most often (4-5 days per week) in their classrooms and constructivist beliefs.

\section{CONCLUSION}

Just adding a technology tool to a traditional teaching approach does not produce more effective instruction and make the process harder and more complex without providing much benefit. In order for technology to be used effectively in the classroom, teachers have to make sure that they are using it as part of an approach that involves the students in the activity. Constructivist approaches, with their focus on student-centered learning, have long advocated student involvement in the process of gaining knowledge and have sought ways for teachers to become advocates in the learning process rather than as figures who only dictate information. This approach seems to be a good match for the technological applications being developed today. While being an advocate of constructivism is not a requirement for the use of technology and while using technology will not necessarily convince someone to change from their traditional teaching approach, the two tend to increase the other, and provide the best results from both an application and a theoretical perspective. By using technology in a constructivist approach, teachers can involve students in learning activities, they can structure the instruction to meet different learning levels and styles, and they can broaden the range of resources that are available to the learner. This allows the technology to be more than just another way to present information; it becomes the system in which information is presented. Technology as part of a learning theory is more than a tool; it becomes the framework for the methodology. For those who are looking for ways to enhance their constructivist approach to instruction, technology provides the ability to support all of the central themes of this theory. Teachers are less hesitant to use technology because they can see that it helps them design their instruction in such a way that supports their theoretical approach. Using the two together technology and constructivist theory - provides a better use and integration of technology tools into the classroom in an effective manner, while giving the teacher the tools necessary to effectively design an instructional model that meets the requirements of a student-centered focus.

\section{ACKNOWLEDGMENT}

We thank Seyedeh Masoumeh Ahmadi, Alizadeh, and Babaee for their extensive and insightful discussions and comments on the paper.

\section{REFERENCES}

[1] T. Teo, "Pre-service teachers' attitudes towards computer use: A Singapore survey," Australasian Journal of Educational Technology, vol. 24, no. 4 pp. 413-424, 2008.

[2] E. Judson, "How teachers integrate technology and their beliefs about learning: Is there a connection?" Journal of Technology and Teacher Education, vol. 14, no. 3, pp. 581-597, 2006.

[3] R. T. Richards, "Infusing technology and literacy into the undergraduate teacher education curriculum through the use of electronic portfolios," T.H.E. Journal, vol. 25, no. 9, pp. 4650,1998 . 
[4] T. Brush, and J. W. Saye, "Strategies for preparing pre-service social studies teachers to integrate technology effectively: Model and practices," Contemporary Issues in Technology and Teacher Education, vol. 9, no. 1, pp. 46-59, 2009.

[5] D. H. Schunk, " Learning theories: an educational perspective," New Jersey: PrenticeHall, 2000.

[6] M. J. Hannafin, and R. J. Hill, "Epistomology and the design of learning environments," In R. A. Reiser, \& Dempsey, J. V. (Ed.), Trends and Issues in Instructional Design and Technology, New Jersey: Merrill Prentice Hall, 2002.

[7] W. L. Saunders, "The constructivist perspective: Implications and teaching strategies for science," School Science Mathematics, vol. 92, no. 3, pp. 136-141, 1992. DOI: $10.1111 / \mathrm{j} .1949$ 8594.1992.tb12159.x

[8] J. G. Brooks, and M. G. Brooks, "The case for constructivist classrooms," Alexandria, VA.: Association for Supervision and Curriculum Development, 1993.

[9] I. Harel, and S. Papert, "Constructionism.," Norwood, N.J.: Ablex Publishing, 1991.

[10] S. Holzer, "From Constructivism to Active Learning," The Innovator, no.2, 1994.

[11]Y. Feng, "Some Thoughts about Applying Constructivist Theories of Learning to Guide Instruction," University of Washington, 1995.

[12]E. von Glasersfeld, "Radical constructivism: A way of knowing and learning," London and Washington: The Falmer Press, 1995.

[13] E. Murphy, "Constructivism from Philosophy to Practice," www.stemnet.nf.ca, 1997.

[14] L. Darling-Hammond, and B. Falk, "Using standards and assessments to support learning," Phi Delta Kappan, vol. 79, no. 3, pp.190-199, 1997.

[15] J. Confrey, "What constructivism implies for teaching," In Constructivist views of mathematics, 1990.

[16]P. Ernest, "Social constructivism and the psychology of mathematics education," In Ernest, P. (Ed.). Constructing mathematical knowledge: Epistomology and mathematical education. Falmer Press, 1994.

[17] N. Noddings, "Constructivism in mathematics education." In Davis R.B. (Ed.). Constructivist views on the teaching and learning of mathematics. Journal for Research in Mathematics Education: Monograph, no. 4. National Council of Teachers of Mathematics, 1990.

[18]M. G. Mikusa, and H. Lewellen, "Now here is that authority on mathematics reform," Dr. Constructivist! Mathematics Teacher, vol. 92, no. 3, pp. 158-163, 1999.

[19] S. Pirie, and T. Kieren, "Creating constructivist environments and constructing creative mathematics," Educational Studies in Mathematics, vol. 23, no. 5, pp. 505-528, 1992. DOI: $10.1007 / \mathrm{BF} 00571470$

[20] S. Hanley, “On constructivism," [On-line]. Available:

http://www.inform.umd.edu/UMS+State/UMDProjects/MCTP/Essays/Constructivism.txt, 1994.

[21]D. Schwartz, "Ghost in the machine: Seymour Papert on how computers fundamentally change the way kids learn," Interview, 1999. Available WWW:

[http://www.papert.org/articles/GhostInTheMachi ne.html].

[22]T. Reeves, "Evaluating what really matters in computer-based education," University of Georgia, 1997. Available WWW: [file:///Macintosh\%20HD/Desktop\%20Folder/rev iewed/reeves.htm].

[23] B. G. Wilson, "Metaphors for instruction: why we talk about learning environments," Educational Technology, vol. 35, no. 5, pp. 2530, $1995 . \quad$ Available WWW: [http://www.cudenver.edu/ bwilson].

[24] D. Maor, "Teachers-as-learners: the role of a multimedia professional development program in changing classroom practice," Australian Science Teachers Journal, vol. 45, no. 3, pp. 45- 51, 1999.

[25] J. Petraglia, "The real world on a short leash: the (mis)application of constructivism to the design of educational technology," E T R \& D, vol. 46, no. 3, pp. 53-65, 1998.

[26]R. Yager, "The constructivist learning model, towards real reform in science education," The Science Teacher, vol. 58, no._6, pp. 52-57, 1991.

[27]B. G. Wilson, "Reflections on constructivism and instructional design, instructional development paradigms," Educational Technology Publications, 1997. Available WWW: [http://carbon.cudenver.edu/ bwilson/construct.ht $\mathrm{ml}]$.

[28] M. Dougiamas, “A journey into constructivism," [On-line]. Available: http://dougiamas.com/wrting/constructivism.html, 1998.

[29] S. Papert, "Papert on Piaget, the century's greatest minds," Time. p. 105, 1999.

[30] K. Dawson, C. Cavanaugh, and A. Ritzhaupt, "Florida's EETT Leveraging Laptops Initiative and its impact on teaching practices," University of North Carolina at Wilmington, vol. 41, no. 2, pp. 143-159, 2008.

[31] B. Drayton, J. K. Falk, R. Stroud, K. Hobbs, and J. Hammerman, "After installation: Ubiquitous computing and high school science in three experienced, high-technology schools," Journal of Technology, Learning, and Assessment, vol. 9, no. 3, 2010.

[32]C. Mouza, "Learning with laptops: Implementation and outcomes in an urban, underprivileged school," Journal of Research on 
Technology in Education, vol. 40, no. 4, pp. 447472, 2008.

[33]H. Wenglinksy, "Does it compute? The relationship between educational technology and student achievement in mathematics," Educational Testing Service, Princeton NJ. Policy Information Centre, 1998.

[34] L. M. O’Dwyer, M. Russell, D. Bebell, and K. R. Tucker-Seeley, "Examining the relationship between home and school computer use and students' English/language arts test scores," Journal of Technology, Learning, and Assessment, vol. 3, no. 3, 2005.

[35] B. Means, "Technology and education change: Focus on student learning," Journal of Research on Technology in Education, vol. 42, no. 3, pp. 285-307, 2002.

[36] K. S. Shapley, C. Maloney, and F. CaranikasWalker, "Evaluating the implementation fidelity of technology immersion and its relationship with student achievement," Journal of Technology, Learning, and Assessment, vol. 9, no. 4, pp. 1-2, 2010.

[37] L. M. Gorder, "A study of teacher perceptions of instructional technology integration in the classroom," Delta PI Epsilon Journal, vol. 2, pp. 63-76, 2008.

[38] K. F. Hew, "Integrating technology into k-12 teaching and learning: Current knowledge gaps and recommendations for future research," Educational Technology, Research and Development, vol. 55, pp. 223-252, 2007.

[39] T. H. S. Eysink, T. deJong, K. Berthold, F. Kolloffel, M. Opfermann, and P. Wouters, "Learner performance in multimedia learning arrangements: An analysis across instructional approaches," American Educational Research Journal, vol. 46, no. 4, pp. 1106-1149, 2009.

[40] J. T. Fouts, "Research on computers and education: Past, present and future," Bill and Melinda Gates Foundation. Available: www.portical.org/fouts.pdf. 2000.

[41] d. Oblinger, "Boomers and gen-xers millennials understanding the new students," Educause Review, vol. 38, no. 4, pp. 37-47, 2003.

[42] D. Brown, M. Warschauer, "From the university to the elementary classroom: students' experience in learning to integrate technology in instruction," Journal of Technology and Teacher Education, vol. 14, no. 3, pp. 599-621, 2006.

[43] J.H.L. Koh, and T. W. Frick, "Instructor and student classroom interactions during technology skills instruction for facilitating pre-service teachers' computer self-efficacy," Journal of Educational Computing Research, vol. 40, no. 2, pp. 211-228, 2009.

[44] P. Hernandez-Ramos, "If Not Here, Where? Understanding Teachers' Use Of Technology In Silicon Valley Schools," Journal of Research on
Technology in Education, vol. 38, no. 1, pp. 3964, 2005.

[45]L. Wozney, V. Venkatesh, P. C. Abrami, 'Implementing computer technologies: Teachers' perceptions and practices," Journal of Technology and Teacher Education, vol. 14, no. 1, pp. 173-207, 2006.

[46] L. Alvine, "A 20th century English teacher educator enters the 21st century: A response to Pope and Golub," Contemporary Issues in Technology and Teacher Education, vol. 1, no. 1, pp. 102-106, 2000.

[47]H. J. Becker, "The exemplary teacher' paper: How it arouses and how it changed its author's research program," Contemporary Issues in Technology and Teacher Education, vol. 1, no. 2, pp. 1-9, 2000.

[48] C. A. Bowman, "Infusing technology-based instructional frameworks in the methods courses: A response to Pope and Golub," Contemporary Issues in Technology and Teacher Education, vol. 1, no. 1, pp. 98-101, 2000.

[49] D. Bullock, "Moving from theory to practice: An examination of the factors that pre-service teachers encounter as they attempt to gain experience teaching with technology during field placement experiences," Journal of Technology and Teacher Education, vol. 12, no. 2, pp. 211224, 2004.

[50] R. Aust, B. Newberry, J. O'Brien, and J. Thomas, "Learning generation: Fostering innovation with tomorrow's teachers and technology," Journal of Technology and Teacher Education, vol. 13, no. 2, pp. 167-180, 2005.

[51] P. Adamy, and W. Heinecke, "The influence of organizational culture on technology integration in teacher education," Journal of Technology and Teacher Education, vol. 13, no. 2, pp. 233-244, 2005.

[52] J. Howland, and J. Wedman, “A process model for faculty development: Individualizing technology learning," Journal of Technology and Teacher Education, vol. 12, no. 2, pp. 239-251, 2004.

[53] J. Burnston, "Proving IT Works," CALICO Journal, vol. 20, no. 2, pp. 219-226, 2003.

[54] K. Sheingold, and M. Hadley, "Accomplished teachers: Integrating computer in classroom practice," New York: Bank Street College of Education, Centre for Technology in Education, 1990.

[55] [55] P. A. Dupin-Bryant, "Variables related to interactive television teaching style: In search of learner-centred teaching styles," International Journal of Instructional Technology and Distance Learning, vol. 1, no. 4, pp. 3-14, 2004.

[56] J. Machnaik, "Investigating the effect(s) of technology integration on teaching practices that may lead to the development of a community of 
learners (Electronic version)," Saskatoon, SK, Canada: University of Saskatchewan, 2002.

[57] A. Dillon, and M. G. Morris, "User acceptance of information technology: Theories and models," Journal of the American Society for Information Science, vol. 31, pp. 3-32, 1996.

[58] J. M. Carroll, M. B. Rosson, D. Dunlap, and P. Isenhour, "Frameworks for sharing teaching practices," Educational Technology and Society, vol. 8, no. 3, pp. 162-175, 2005.

[59] L. Cuban, "Oversold and underused: Computers in the classroom," London: Harvard University Press, 2001.

[60] Y. Zhao, and G. A. Cziko, "Teacher adoption of technology: A perceptual control theory perspective," Journal of Technology and Teacher Education, vol. 9, pp. 5-30, 2001.

[61] S. Parks, D. Huot, J. Hamers, and F. H. Lemonnier, "Crossing boundaries: multimedia technology and pedagogical innovation in a high school class," Language Learning and Technology, vol. 7, no. 1, pp. 28-45, 2003.

[62]C. Chen, "Why do teachers not practice what they believe regarding technology integration?" Journal of Educational Research, vol. 102, no. 1, pp. 65-75, 2004.

[63] G. Dudeney, and N. Hockly, "'How to teach English with technology?" Harlow: Pearson Education Limited, 2007.

[64]M. Liu, and H. Huo, "Computer Assisted Language Learning (CALL) in China: Some common concerns," US-China Foreign Language, vol. 5, no. 1, pp. 52-58, 2007.

[65]C. N. Park, and J. B. Son, "Implementing computer assisted language learning in the EFL classroom: Teacher perceptions and perspectives," International Journal of Pedagogy and Learning, vol. 5, no. 2, pp. 80-101, 2009.

[66] S. L. Dexter, R. E. Anderson, and H. J. Becker, "Teachers' views of computers as catalysts for changes in their teaching practice," Journal of Research on Computing in Education, vol. 31, pp. 221-238, 1999.

[67] K. Mitchem, D. Wells, and J. Wells, "Effective integration of instructional technologies (IT): evaluating professional development and instructional change," Journal of Technology and Teacher Education, vol. 11, no. 3, pp. 397-414, 2003.

[68] J. Bauer, and J. Kenton, "Toward technology integration in the schools: Why it isn't happening," Journal of Technology and Teacher Education, vol. 13, no. 4, pp. 519-546, 2005.

[69]C. Q. Yang, "A research study on teacher professional development in technology-rich educational environment," Teacher Professional Development Forum, Retrieved on June 20, 2009 from http://www.ckni.net, 2008.

[70]M. Shi, and B. A. Bichelmeyer, "Teachers' experiences with computers: A comparative study," Educational Technology and Society, vol. 10, no. 2, pp. 180-190, 2007.

[71] R. C. Wei, L. Darling-Hammond, A. Andree, N. Richardson, and S. Orphanos, "Professional learning in the learning profession: A status report on teacher development in the United States and abroad," Dallas, TX: National Staff Development Council, 2009.

[72] G. Li, and M. S. Protacio, "Best practices in professional development for teachers of ELLs," In G. Li and P. Edwards (Eds.), Best practices in ELL instruction. NY: Guilford Press, 2010.

[73]D. S. Bennahum, "School's out? Interview of Seymour Papert," Available WWW: http://www.papert.org/articles/SchoolsOut.html, 1996.

[74]D. Jonassen, "There is No Need to Reclaim the Field of ID: It's Just Growing," Available WWW: [http://www.ittheory.com/jonassen1.htm, 1996.

[75] M.G. Jones, "Learning to play; playing to learn: lessons learned from computer games," Available WWW: [http://intro.base.org/docs/mjgames, 1997.

[76]D. H. Jonassen, C. Carr, and H. P. Yueh, "Computers as Mindtools for engaging learners in critical thinking," Tech Trends, vol. 43, no. 2, pp. 24-32, 1998.

[77]K. Muller, "Constructivism in education," Katholische Universitat Eichstatt, Germany. Available WWW: [http://www.fb10.unibremen.de/romanistik/DGFF/Mueller.htm].

[78] S. Rodrigues, "The interpretive zone between software designers and a science educator: grounding instructional multimedia design in learning theory," Journal of Research on Computing in Education, vol. 33, no. 1, p. 1, 2000.

[79] D. Brown, "Kids, computers and constructivism," Journal of Instructional Psychology, vol. 23, no. 3, pp. 189- 196, 1996.

[80] S. Papert, "Computer as material: messing about with time," The Teachers College Record, vol. 89 no. 3, 1998. Available WWW: [http://www.papert.org/articles/ComputerAsMate rial.html]

[81]S. Cohen, "Review of Seymour Papert, the children's machine: rethinking school in the age of the computer (New York: Basic Books, 1993); and Seymour papert, the connected family: bridging the digital generation gap (Atlanta: Longstreet Press, 1996)" Available WWW: http://www.ilt.columbia.edu/academic/classes/T U4000/Reviews/Paper93_Coh.html, 1993.

[82]B. Muniandy, R. Mohammad, and S. F. Fong, "Synergizing pedagogy, learning theory and technology in instruction: How can it be done?" US-China Education Review, vol. 34, no. 4, pp. 46-53, 2007. 
[83] G. C. Rakes, V. S. Fields, and K. E. Cox, "The influence of teachers' technology use on instructional practices," Journal of Research on Technology in Education, vol. 38, no. 4, pp. 409424, 2006.

[84] D. Jonassen, “Objectivism vs constructivism: Do we need a new philosophical paradigm?" Educational Technology, Research and Development, vol. 39, no. 3, pp. 5-13, 1991.

[85]R. McClintock, "Power and pedagogy: Transforming education through information technology," New York: Teachers College Press, 1992.

[86]D. H. Jonassen, K. Peck, and B. Wilson, "Learning with technology: A constructivist perspective," Upper Saddle River, NJ: PrenticeHall Inc, 1999.

[87] S. Lajoie, and S. Derry, "Computers as Cognitive Tools," LEA: Hillsdale, NJ, 1993.

[88] D. H. Jonassen, "Computers as mind-tools for schools: Engaging critical thinking," Columbus, OH: Prentice-Hall, 2000.

[89]R. Tretten, and P. Zachariou, "Learning about project-based learning: Self-assessment preliminary report of results," San Rafael, CA: The Autodesk Foundation, 1995.

[90]K. Ryba, M. E. Brown, "How proficient IT teachers integrate computers into the curriculum," Journal of Computing in Teacher Education, vol. 16, pp. 6-11, 2000.

[91]B. Means, and K. Olson, "Technology and education reform," Washington, DC: U.S. Department of Education, 1997.

[92]E. M. Riddle, "Communication through multimedia in an elementary classroom," Charlottesville, VA: Curry School of Education, University of Virginia. (ERIC Document Reproduction Service No. ED 384 346), 1995.

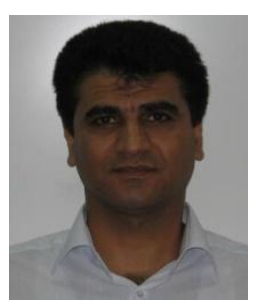

Abbas Pourhosein Gilakjani was born in Roodsar, Iran. The author has received B.A. degree in the field of English Language Translation from the Islamic Azad University of Tonekabon Campus, Mazandaran, Iran.. He has also received M.A. degree in the field of Teaching English as a Foreign Language from the Islamic Azad University of Garmsar Campus, Semnan, Iran.

$\mathrm{He}$ has been teaching English in the English Translation Department at the Islamic Azad University of Lahijan, Guilan, Iran from 1999 to 2010. He was the Head of English Translation Department from 2007-2009. He is studying Ph.D. in TESOL at the USM, Malaysia. His publications are: (1) The Effect of Information and Communication Technology on Teaching and Learning (India, ELT Weekly Journal, vol.3 Issue\#79 January, 17, 2011. (2) Role of Consciousness in Second Language Acquisition (Finland, TPLS Journal, Issue 5, May, 2011. (3) Why Is Pronunciation So Difficult To Learn?
(Canada, ELT Journal, vol. 4, no. 3, September, 2011). His main interests are English pronunciation instruction, speaking skill, listening skill, technology, motivation, and reading comprehension skill.

Pourhosein Gilakjani is the Faculty Member of the Islamic Azad University of Lahijan, Iran.

Lai-Mei Leong is a senior lecturer at the School of Educational Studies, Universiti Sains Malaysia. Her fields of expertise include ICT in Education and English Language Teaching.

Hairul Nizam Ismail received his Ph.D. (Educational Psychology/Instructional System Technology) from Indiana, United States of America in 1999, with specialization in the area of learning and cognition. Since that year, he has served as the faculty member at the School of Educational Studies, Universiti Sains Malaysia. For the past 11 years, he has been teaching many university courses related to educational psychology, child psychology, cognitive psychology, guidance and counseling, multiple intelligences, gifted and talented, thinking and reasoning, and psychological testing. He has written numerous journal and magazine articles, research monographs, as well as book chapters in similar topic areas. He is currently the deputy dean of graduate studies and research at the School of Educational Studies, Universiti Sains Malaysia. 